\title{
CREATING FLEXIBILITY TO MEET CHANGING COMPUTER LITERACY REQUIREMENTS
}

\author{
Kent White, Nicholls State University, kent.white@nicholls.edu \\ Lori Soule, Nicholls State University, lori.soule@nicholls.edu
}

\begin{abstract}
In the past, computer literacy consisted of a single course covering basic productivity software. While the content of this course met the university requirements, this format did not allow programs of study to choose requirements that more closely fit with their curriculum. By going to one hour modules on different literacy topics, the programs can more easily pick the courses that suit their needs and increase the student's depth of knowledge about a particular topic. The paper discusses the process of moving from a three-hour course to several one hour modules. The problems encountered along with possible solutions are discussed. In addition, future evaluations to be used to determine of success of the new modules are discussed.
\end{abstract}

Keywords: Computer Literacy, Degree Requirements, Word Processing, Spreadsheets, Databases, Presentation Software

\section{INTRODUCTION}

In a time when universities are being made more accountable for retaining and graduating students, under attack are number of hours a student must complete in order to graduate. In a recent mandate from the state's Board of Regents, a call for a system-wide 120 hour degree requirement standard was announced [3]. At the authors' institution, most of the programs had 121 required hours because of a one-hour university studies introductory course, UNIV 101. The university decided that the university mandated computer literacy requirements would be reduced from three hours to two hours.

This paper describes the recent activities that transpired at the authors' institution as the university reduced the required numbers of hours in their degrees. Initially presented as a need to remove computer literacy from the curriculum, a decision to reduce the number of hours from one three-hour course to two one-hour modules was made. This change resulted in all departments deciding which modules would be required of their students. In the process of the changes, problems were encountered and possible solutions were found.

In fall 2009, the university general education committee met with the charge of looking at various ways the general education requirements could be reduced by one hour. The committee looked at making the university studies course a zero hour course. However, the committee felt that the students would have no incentive to place any effort in a zero-hour course. The committee then looked at reducing the speech requirement from three to two hours. Some faculty stated that the students sat in the class listening to speeches made by other students which warranted them only getting two hours of credit. The committee decided to leave speech as a three hour class.

Next, the committee looked at eliminating the computer literacy requirement entirely from the university requirements. However, many faculty objected to this. The faculty felt that while students may know how to use Facebook and Twitter they did not all have the necessary skills to meet the various degree requirements at the university. In addition, most but not all high school graduates have been exposed to productivity software and nontraditional students had minimal, if any, exposure [4].

In support of faculty protesting the removal of a computer literacy course, Palaigeorgiou, Siozos, and Kostantakis [11] stated that higher education students possess differing level of computer skills and technology knowledge resulting in the need for the course. Also, students possess a sense of confidence when they are capable of creating content when using computer applications [2]. In addition, students taking computer literacy and applications courses had positive attitudes toward computer applications [5]. 
While there is no agreement of what content should be contained in a computer literacy course, the topic of computer literacy is very relevant to students, educators, and future employers [6]. "Universities have been challenged to develop computer literacy content as students make the transitions from high school to the workshop" [6]. The National Education Technology Standards (NETS) Project has developed national standards for students. The NETS Project was developed by the International Society for Technology in Education. Included in this project is a set of performance indicators in which students should be able to demonstrate the "use of technology systems... and should be able to use applications effectively and productively" [7].

Besides gaining the necessary knowledge to complete assignments while in college, both business and education see the need for computer literary. Most companies and especially Fortune 500 companies are requiring computer literate employees at all levels [12]. Educators are seeing themselves as being responsible for preparing students for the future and included in this preparation is information technology [9]. Technology must become integrated into the educational environment through a much wider context; this will require technology being used in the classroom and positive attitudes must exist for technology to succeed [8].

With all of the positive support for the need of computer literacy courses, at some universities certain programs do not require a basic computer course for incoming freshmen because students were arriving on campus "computer literate" [1]. Andrew Nikiforuk [10] argues that computer literacy does not "provide any significant improvements than traditional education".

Knowing the importance of requiring some type of computer literacy course as part of a student's general education requirement, the authors' institution had been offering three different three-hour computer literacy courses:

- Computer Literacy I (Introduction to Microsoft Word and Excel—CMPS 101),

- Computer Literary II (Introduction to Microsoft PowerPoint and Access, Advanced Word and ExcelCMPS 202), and

- Computer Technology for Science Majors (Introduction to Microsoft Word, Excel, PowerPoint and Access-CMPS 200).

On an average semester, 12-15 sections of Computer Literacy I was offered, one section of Computer Literacy II, and one or two sections of Computer Technology for Science Majors. Computer Literacy I and Computer Technology for Science Majors were offered in both a web and traditional setting.

From this discussion, in spring 2010, a decision was made by senior administration to break the literacy requirements into one-hour modules and allow the various degree programs to pick the classes that would allow the students to get the necessary skills required by their programs.

The one-hour modules selected were Introduction to Word Processing (CMPS 107), Advanced Word Processing (CMPS 207), Introduction to Spreadsheets (CMPS 108), Advanced Spreadsheets (CMPS 208), Introduction to Database Applications (CMPS 209), and Introduction to Presentation Software (CMPS 109). The courses were approved by the Courses and Curricula Committee in spring 2011 and they were offered to students beginning in summer 2011. The computer literacy faculty decided to offer one-hour mini modules that will last only one-half of a semester. Using this time frame, students would be able to take both required classes at the same time period for the semester. The students completing Introduction to Word Processing and Introduction to Spreadsheets would cover the same content as when the course Computer Literacy I was taught; the difference would be they would earn a total of two hours of credit for the two introduction courses where before students would earn three hours of credit for the computer literacy course.

Table 1 displays the selection of the required literacy courses for each of the degree programs at the authors' university. Most departments require their students to complete two computer literacy courses taught by the computer literacy faculty in order to meet the meet the university computer literacy requirement. However, the College of Education and the Department of Music require their students to take a computer literacy course created and taught by their own faculty. In the College of Education course, students are introduced to technologies needed for successful implementation of technology-based lessons and universal designs for exposed learning while in the 
Department of Music course, students are introduced to application software for use in music, digital keyboards, MIDI, music notation, music publishing, and computer assisted instruction.

Table 1. Listing of computer literacy requirements by degree programs

\begin{tabular}{|c|c|c|}
\hline Department/Concentration & First Choice & Second Choice \\
\hline Accounting & Spreadsheets & Databases \\
\hline Art & Any 1-hour computer literacy module & $\begin{array}{l}\text { Any 1-hour computer literacy } \\
\text { module }\end{array}$ \\
\hline Athletic training & $\begin{array}{l}\text { Choice of Word processing or } \\
\text { Presentation software }\end{array}$ & Spreadsheets \\
\hline Biology & Spreadsheets & Presentation software \\
\hline Business Administration & Spreadsheets & Databases \\
\hline Chemistry & Introduction to Computer Science I & \\
\hline College of Education & their own course & \\
\hline Communicative Disorders & $\begin{array}{l}\text { Choice of Word processing or } \\
\text { Spreadsheets }\end{array}$ & $\begin{array}{l}\text { Choice of Spreadsheets or } \\
\text { Presentation software }\end{array}$ \\
\hline Computer Information Systems & Spreadsheets & Databases \\
\hline Culinary Arts & Spreadsheets & Advanced spreadsheets \\
\hline Dietetics & Any 1-hour computer literacy module & $\begin{array}{l}\text { Any 1-hour computer literacy } \\
\text { module }\end{array}$ \\
\hline Finance & Spreadsheets & Databases \\
\hline $\begin{array}{l}\text { General Family \& Consumer } \\
\text { Sciences }\end{array}$ & Any 1-hour computer literacy module & $\begin{array}{l}\text { Any 1-hour computer literacy } \\
\text { module }\end{array}$ \\
\hline Geomatics & $\begin{array}{l}\text { Introduction to Computer Science I or } \\
\text { Spreadsheets \& Presentation software }\end{array}$ & \\
\hline Government & Any 1-hour computer literacy module & $\begin{array}{l}\text { Any 1-hour computer literacy } \\
\text { module }\end{array}$ \\
\hline History & Any 1-hour computer literacy module & $\begin{array}{l}\text { Any 1-hour computer literacy } \\
\text { module }\end{array}$ \\
\hline Management & Spreadsheets & Databases \\
\hline Marketing & Spreadsheets & Databases \\
\hline Math & $\begin{array}{l}\text { Introduction to Computer Science I or } \\
\text { Introduction to Computer Science II }\end{array}$ & \\
\hline Music & their own course & \\
\hline Nursing & Spreadsheets & Databases \\
\hline Pre-Clinical Laboratory Science & Spreadsheets & Presentation software \\
\hline Pre-Dental Hygiene & Spreadsheets & Presentation software \\
\hline Pre-Medical/Pre-Dental Chemistry & Introduction to Computer Science I & \\
\hline Pre-Pharmacy & none & \\
\hline Psychology & Any 1-hour computer literacy module & $\begin{array}{l}\text { Any 1-hour computer literacy } \\
\text { module }\end{array}$ \\
\hline Sociology & Any 1-hour computer literacy module & $\begin{array}{l}\text { Any 1-hour computer literacy } \\
\text { module }\end{array}$ \\
\hline
\end{tabular}

\section{Paring of Courses}

The authors' wanted to integrate the computer literacy courses with the university studies course because the university studies course grouped the students together by major. With the students grouped by major, this allowed the tailoring of the sections offered to the sections needed by each major. The university studies classes would meet one day a week while the computer literacy courses would meet at the same time on two other days of the week. 
The computer literacy will be offered as a hybrid course where the students would meet one day in a face-to-face setting and the other day would be optional; students needing additional help or time to complete the assignments would attend class. The student will take the university studies course for the entire semester while taking the first literacy class the first half of the semester and the second literacy the second half of the semester. Table 2 displays an example of the schedule for the university studies and computer literacy classes for culinary and business majors.

Table 2. Example of meeting days for classes

\begin{tabular}{|c|c|c|}
\hline & Day of week/section/class length & Course \\
\hline \multirow{5}{*}{$\begin{array}{l}\text { Culinary majors - } \\
\text { group } 1\end{array}$} & Monday/3M/entire semester & UNIV 101 \\
\hline & Wednesday/3M/first half of semester & Spreadsheets in face-to-face setting \\
\hline & Friday/3M/first half of semester & Spreadsheets - optional meeting \\
\hline & Wednesday/3M/second half of semester & Advanced Spreadsheets in face-to-face setting \\
\hline & Friday/3M/second half of semester & Advanced Spreadsheets - optional meeting \\
\hline \multirow{5}{*}{$\begin{array}{l}\text { Culinary majors - } \\
\text { group } 2\end{array}$} & Wednesday/3M/entire semester & UNIV 101 \\
\hline & Monday/3M/first half of semester & Spreadsheets in face-to-face setting \\
\hline & Friday/3M/first half of semester & Spreadsheets - optional meeting \\
\hline & Monday/3M/second half of semester & Advanced Spreadsheets in face-to-face setting \\
\hline & Friday/3M/second half of semester & Advanced Spreadsheets - optional meeting \\
\hline \multirow{5}{*}{$\begin{array}{l}\text { Business majors - } \\
\text { group } 1\end{array}$} & Monday/5M/entire semester & UNIV 101 \\
\hline & Wednesday/5M/first half of semester & Spreadsheets in face-to-face setting \\
\hline & Friday/5M/first half of semester & Spreadsheets - optional meeting \\
\hline & Wednesday/5M/second half of semester & Databases in face-to-face setting \\
\hline & Friday $/ 5 \mathrm{M} /$ second half of semester & Databases - optional meeting \\
\hline \multirow{5}{*}{$\begin{array}{l}\text { Business majors - } \\
\text { group } 2\end{array}$} & Wednesday /5M/entire semester & UNIV 101 \\
\hline & Monday /5M/first half of semester & Spreadsheets in face-to-face setting \\
\hline & Friday/5M/first half of semester & Spreadsheets - optional meeting \\
\hline & Monday $/ 5 \mathrm{M} /$ second half of semester & Databases in face-to-face setting \\
\hline & Friday/5M/second half of semester & Databases - optional meeting \\
\hline
\end{tabular}

As one can determine from Table 2, those students taking the university studies class on a Monday will attend the face-to-face class on Wednesday and those students taking the university studies class on Wednesdays will attend the face-to-face class on Monday. The two classes will then be combined on Fridays so students can come in for individual help or needed time to complete assignments during the same time period. Using this scheduling mechanism allows a student to get three hours of credit in a regular time slot in which a single three hour class is usually held even though they will be taking three separate classes. Since the authors' university employs professional advisors that determine the students' schedules through their sophomore year, scheduling the correct one-hour modules should not be a problem, especially since the approach is to enroll the students in the computer literacy modules during their first semester. For students not scheduling the needed courses during their first semester, the departments have informed their students of the course changes.

\section{Problems Encountered}

With the unusual arrangement of the classes, solutions for problems or possible problems were needed. The first problem that occurred was students not realizing that they needed to schedule two courses to meet the university requirement for computer literacy where as in the past, only one course was needed. This was not a problem for incoming freshman; they are grouped by major interest in the university studies course. The University College advisors were made aware offor the class arrangements and were able to easily schedule classes for the freshman. This class arrangement allowed the computer literacy courses to be tailored for each major. For example, the culinary majors must complete the introduction and advanced spreadsheet courses. The class arrangement allowed for both of these courses to be placed at the same time as the university studies time period. The problem occurred 
with the older students; some students' schedule of coursework has computer literacy placed in their sophomore year. Since they do not take the course in their freshman year, they were not aware of the unusual arrangement of the classes. To address this issue, each computer literacy instructor contacted the students registered for any computer literacy class to make sure they registered for a second class.

Another problem that will most probably occur will be the situation where a student enrolls in two computer literacy courses; the second course has a prerequisite of the first course. If the student fails the first course they will need to be dropped from the second course. A mechanism has been created by the university's registrar to address this situation. Students that do not pass the first course will be automatically dropped from the second course. Also, for courses that start at the beginning of the semester, final grades will be entered when the class ends at mid-semester. In addition, drop dates will be changed to accommodate those courses that end at mid-semester and those courses that begin at mid-semester. The students will need to be made aware of all of these changes at the beginning of the semester since these modules are not like the typical semester course.

A third problem that probably will occur will result in students needing to take more than two computer literacy courses. Students will need to realize that if they change majors the computer literacy requirements may also change.

A very recent problem occurring this summer is that because the students are spread across multiple courses, some courses did not have a high enough enrollment count for the course "to make". An example of this situation was 12 students enrolled in CMPS 107, 9 in CMPS 108 (all were also enrolled in CMPS 107), and 2 in CMPS 109 (all were also enrolled in CMPS 107). Because of the minimal head count of 10 students for a course to be offered, both CMPS 108 and CMPS 109 were cancelled. A solution would be to offer a course during the summer and intersession semesters that would contain all six modules. Students would be responsible for completing the content of the sections needed for their curriculum. This course would be a two hour course. In the given example, the 12 students enrolled in the combination of computer literacy courses, CMPS 107/108 or CMPS 107/109, would have been able to complete both hours of computer literacy. The authors will be presenting this newly designed course to their Courses and Curricula Committee this fall.

\section{Possible Bright Spots}

Since the students are grouped by interest, the faculty teaching the courses will be able to offer more targeted assignments that directly relate to the students' curriculum. These targeted assignments should interest the students more than just a generic assignment that has no relation to their interest. Also, since the students are taking more than one class together they should be to develop contacts that would not normally be available in a class of mixed majors. There could be a common theme developed for the class that more closely resembles their interest.

\section{Future Evaluation}

In order to determine if the approach of offering the one-hour modules over an 8-week period is successful, a short survey will be administered to all students enrolled in the modules. The survey will be created using Google forms and will consist of 4-point Likert scale questions, forced choice questions, and open-ended questions. The authors are wondering if the 8-week presentation of one module followed by second 8-week presentation of a second module is the best approach when no pre-requisites are involved. The authors are also questioning if the students would prefer to complete both 8-week modules at once. Since the current summer semester is the first time the onehour modules are being implemented, the authors are interested in the opinions of the students experiencing this new format.

\section{CONCLUSIONS}

Even in today's world of ubiquitous technology, the literature reflects the need for computer literacy. Knowing how to post in social media does not teach students the necessary skills needed to complete assignments for their courses. By breaking the computer literacy classes into one-hour modules, the faculty will be given the flexibility to better 
Volume XII, No. 2, pp 123-128, 2011

meet the needs of the various programs and students on campus. If a department's needs change in the future, the one-hour courses will be easier to modify with this setup than having a "one-size fits all" course for all programs. The students will also get to know other students majoring in the same field better because all students in the class will have the same major. Also, faculty will need to be flexible in accommodating problems as they occur. Seeing that the one-hour modules would not work under certain conditions brought up the need for an additional course and the faculty were willing to respond to this need.

\section{REFERENCES}

1. Baugh, J. M. \& Morris, R. (2003). Assessment of spreadsheet and database skills in the undergraduate student. Proceedings of ISECON2003, V20, November.

2. Bers, M. U. (2010). Beyond computer literacy: Supporting youth's positive development through technology. New Directions for Youth Development, 128, 13-33. Retrieved May 12, 2011 from http://scholar.google.com.

3. Board of Regents. (2010, March 4). Regents calls for review of excessive hours for degrees [Press release]. Retrieved from http://regents.louisiana.gov/assets/docs/PublicRelations/2010/120Hours0310.pdf

4. Cammack, N. (2008). Comparison of self-perceptions of computer literacy and skills proficiency assessment of college students in entry level technology courses. Dissertation Abstracts International, 71(08). (Document ID: 2098027141).

5. Erlich, Z., Gadot, R., \& Shahak, D. (2009). The effect of computer literacy course on students' attitudes toward computer applications. Journal of Educational Technology Systems, 37(1), 83-95.

6. Hindi, N. M., Miller, D., \& Wenger, J. (2002). Computer literacy: Implications for teaching a college-level course. Journal of Information Systems Education, 13(2), 143-151.

7. International Society for Technology in Education (2007). NETS for Students 2007. Retrieved July 6, 2011 from International Society for Technology in Education: http://www.iste.org/standards/nets-for-students/nets-studentstandards-2007.aspx

8. Kosakowski, J. (1998). The benefits of information technology ERIC Digest. Retrieved July 6, 2011 from the ERIC database.

9. Kretovics, M. \& McCambridge, J. (1998). Determining what employers really want: Conducting regional stakeholder focus groups. Journal of Careet Planning \& Employment, 58(2), 25-27.

10. Murray, J. \& Kinnick, N. (2003). Contemporary literacy: Essential skills for the $21^{\text {st }}$ century, Multimedia Schools, 10(2), 15-18.

11. Nikiforuk, A. (2000). Digital dunderheads. Canadian Business, 73(4), 12-14.

12. Palaigeorgiou, G. E., Siozos, P. D., \& Konstantakis, N. I. (2006). CEAF: A measure for deconstructing students' prior computer experience. Journal of Information Systems Education, 17(40), 459-468.

13. Zhao, J. \& Alexander,M. (2002). Information technology skills recommended for business students by Fortune 500 executives, Delta Pi Epsilon Journal, 44(3), 175-189 